\title{
Involvement of Female Ex-Conflict Actors in Micro, Small and Medium Enterprises in Aceh
}

\author{
Suadi Zainal ${ }^{1 *}$, Muhammad bin Abubakar ${ }^{2}$, Muktaruddin $^{3}$, and Zulkifli ${ }^{4}$ \\ ${ }^{I}$ Master of Sociology Department Universitas Malikussaleh \\ ${ }^{2}$ Master of Public Administration Department Universitas Malikussaleh \\ ${ }^{3,4}$ Student in Master of Sociology Department Universitas Malikussaleh \\ *Corresponding author email:suadi@unimal.ac.id
}

\begin{abstract}
Entrepreneurship is seen as a mechanism to facilitate prosperity and peace. This study aims to explain the involvement of former conflict actors in Micro, Small and Medium Enterprises (MSMEs) which research subject focus on female ex-conflict actor of Aceh Free Movement. This study was conducted with a qualitative approach. However, this article only used secondary data derived from online journals. The data were analyzed interactively by the content analysis method. The results showed that female ex-conflict actors were involved in MSMEs as small business actors and most were operated in their own home. Thus, the businesses have not led them to large opportunities to enjoy peace dividends.
\end{abstract}

Keywords: Reintegration, conflict actor, peace, enterprises

\section{INTRODUCTION}

The continuation of the Aceh peace that has been going on for a decade and a half is a sign that Aceh's economic growth is starting to improve, although it is seen as slow. Good economic growth will lead to poverty reduction which contributes to peace. Therefore, it cannot be denied that the ability of businesses to generate employment opportunities can promote economic and social development that is able to prevent conflicts from recurring. [1]. One of the paths for economic growth is through entrepreneurship development. In former conflict countries, entrepreneurship is seen as a mechanism to facilitate prosperity and peace [2].

Understanding the crucial role of entrepreneurship, the Aceh Government through the Regional Planning Agency has prepared a Regional Innovation System Roadmap (SIDa). The important thing in this innovation are Micro, Small and
Medium Enterprises (MSMEs). It has a strategic role in encouraging economic growth and reducing the number of unemployed. For this reason, district / city governments are required to develop and strengthen the integration of increasing MSMEs resources[2]. Thus, MSMEs can provide satisfactory economic benefits to their members and continue to exist in the face of local and global market competition.

The growth of MSMEs in Aceh continues to increase every year and particularly in North Aceh there are 2055 MSMEs registered at the Ministry of Cooperatives and SMEs. This is inseparable from the peaceful Aceh situation, and the many stimulants of community economic empowerment assistance allocated by the Government and donor agencies to the Acehnese community, especially for former combatants and civilian GAM and 
conflict-affected communities, especially those who do not have access to resources future economic benefits. Some of the conflict elite actors have transformed into political elites[3] and contractors and rent seekers to obtain economic benefits after the conflict[4, 5]. As a result, Aceh's development program and political economy are under a patronage system controlled by former combatant conflict actors $[6,7]$ so that peace dividends do not function optimally in reducing poverty and injustice in Aceh [8].

Based on this description, it can be assumed that some former middle and lower class conflict actors have transformed into small and medium entrepreneurs along with other creative communities in their villages. However, no research has yet been seen that focuses on the involvement of former conflict actors as MSME actors in an effort to improve economic welfare, especially female combatants. This study aims to explain the growth of MSMEs in North Aceh involving former Aceh conflict actors as part of economic reintegration, particularly female actors. This article explains this problem with a qualitative approach, using secondary data from national and international journals. The data were analyzed using the content analysis method.

\section{LITERATURE REVIEW}

Once young girls and women entered into the insurgency mission, they were required to perform new roles as combatants, informers, organizers of cultural events, cooks, logistics suppliers, nurses to treat wounded fighters, and even to play the role of girlfriends for the male insurgents [9]. However they limited access to resources when peace come, they were marginalized from for social, politic, and economic program[10-12].
Economic reintegration provides assistance and access to employment through job training, skill development, micro-enterprise support, rural development activities and employment promotion. These implies ex-combatants' financial independence through productive and decent work[12].

This description explains that MSMEs in former conflict areas functioned as economic reintegration mechanisms for ex-combatants. Reintegration consists of short and longterm reintegration. For short-term, is reinsertion. It comprises the early period when ex-combatants come to their former family or community. Frequently they are provided with basic household goods, land, food supplements and housing materials. While reintegration is a longer process to incorporate the ex-combatant and his/her family into civilian society, and to attain financial independence through involvement in productive activities. Reintegration may be categorized into two inter-related elements: social and economic, which should proceed in parallel.

There are two approaches to reintegration; narrowly objective and broadly. The first, to eliminate potential threats to public security, deals directly with its target group of ex-combatants and their family members, and may include other vulnerable groups such as unemployed youth, internally displaced persons and others who may constitute a destabilizing influence in the community. The second, is to develop community. It deals with the issue as part of an integrated area-development program of reconstruction and reintegration. The programs focus on communities with a large percentage of target beneficiaries, rather than on the beneficiaries themselves. [13]. 


\section{FINDINGS AND DISCUSSION}

In general, in Indonesia, women who involve in enterprise tend to own more small enterprises; medium-sized enterprises are not so common for them. More women own businesses are informal and with lower turnover than are those of men. Women more often opt for businesses in trade or services and less often in manufacturing, except for food, textiles and garments production[14]. It is similar to women in England, most women do not opt to develop growthoriented businesses, they owned enterprises tend to be smaller in employee count and revenues and most of them are concentrated in the services economic sector [15].

In Aceh, the history has proven that Acehnese women have a strategic role in political development in Aceh, as kings and warlords [16]. The group of women who were involved in the war was known as the Inong Balee Army. This term[17, 18] was still used during the civil war in Aceh (Free Aceh Movement, GAM - Indonesian Government). After the peace agreement, their activities in politics were marginalized. The result, theywas forgotten/marginalized to access of the benefits of the Aceh peace program. This condition prompted them to form a Liga Inoeng Balee Aceh (LINA) as a forum for their struggle for their rights, but its programs tended to be educational, rather than providing economic assistance [19].

Thus, the women are not yet advanced in economic. For examples, in Aceh Besar, they choose rice field farming as an economic source, in Aceh Utara, they process anchovies and timber fish, and embroidery. In Bireun and Pidie most of them run business such as provision shops including, dry fish, fruit crackers, coffee shops and food stalls in the market area.However, they are still suffering from any social and economic challenging [16]. Only few female combatants were given opportunities to take up economic sector, were already closely affiliated to the GAM leadership during the struggle [17]. Most women ex- combatants, lost opportunities to enhance their welfare.[18]. These all indicate that the reintegration policy has failed to reach the poorest ex-fighters, especially women ex-combatants. Giving ex-combatants economic assistance is useful for short term economic relief but in the long run it cannot guarantee the sustainability of their livelihoods.[18].

Indeed, these kinds of activities will not lead them gain a real empowerment. The women who are engaged in these types of activities become less interested in moving forward; they are stuck with the idea of home industry and have no motivation to be an agent of change in their community. They have no interest to join social/political meetings, no interest in participating in the decision making process in their village. Even worse, by a little economic successes they have attract others to do the same, so they are too busy in such activities, they are no longer concerned with the inclination to progress to a higher level[19].

These facts have led them be more dependent on men or men ex-combatants, such as in North Aceh, the women whose husband died in the conflict only received what men share in incidental moment (ex. Meugang Day)[20]. It reveals that the empowerment and economic assistance for women widows of GAM are very few.ExGAM and local government are no longer in line with the original goal of empowering widows of conflict victims[21]. Meanwhile, male ex-GAM combatants and non-combatants, in order to obtain economic resources, they set up several companies, such as limited companies (PT), (CV) and cooperatives. Generally engaged in contracting, and some of them become individual economic brokerage brokers. The tender process for 
government projects involves them, either directly or indirectly[22].

\section{CONCLUSION}

The Aceh conflict resolution model has been used as a lesson for other conflict resolution in Asia. However, this does not appear to have provided a good lesson in the process of economic reintegration. Many economic programs (MSMEs) have neglected the involvement of women, especially those who during the conflict period were highly valued for their role in carrying out the struggle for independence. What happened in Aceh was not very different from what was experienced by other women who were former conflict actors in former conflict areas. They are marginalized in the peace building program. In the economic aspect, they are only involved in small economic enterprises operating at home and their market reach is limited in the local market.

\section{REFERENCES}

1. Chang, J.H. and G. Rynhart, Enterprise creation, employment and decent work for peace and resilience the role of employer and business membership organizations in conflict zones in Asia. 2016, International Labour Organization.

2. Muhammad, S., E. Supriadi, and T.M. Rizki. Keragaan Usahatani Nilam Di Kecamatan Sampoinet Kabupaten Aceh Jaya. in Prosiding Seminar Nasional Pascasarjana Unsyiah. 2017.

3. Stange, G. and R. Patock, From rebels to rulers and legislators: The political transformation of the Free Aceh Movement (GAM) in Indonesia. Journal of Current Southeast Asian Affairs, 2010. 29(1): p. 95-120.

4. Aspinall, E., Combatants to contractors: the political economy of peace in Aceh. Indonesia, 2009(87): p. 1-34.
5. Hajad, V., Peran Mantan Kombatan GAM dalam Sektor Ekonomi Pasca Konflik JPP (Jurnal Politik Profetik), 2019. 7(1): p. 59-79.

6. Lee, T., Political orders and peacebuilding: ending the Aceh conflict.Conflict, Security \& Development, 2020. 20(1): p. 115-139.

7. Barron, P., E.A. Rahman, and K. Nugroho, The Contested Corners of Asia: Subnational Conflict and International Development Assistance: The Case of Aceh, Indonesia. 2013: Asia Foudation.

8. Sustikarini, A., Financing Peace: Special Autonomy Fund as a Peace Dividend in Aceh, Indonesia. JAS (Journal of ASEAN Studies), 2019. 7(2): p. 99-121.

9. Upreti, B.R., S. Shivakoti, and K. Bharati, Frustrated and confused: Mapping the socio-political struggles of female ex-combatants in Nepal. Journal of International Women's Studies, 2018. 19(4): p. 32-52.

10. Ortega, L.M.D. and L. Maria, Transitional justice and female excombatants: Lessons learned from international experience. Disarming the past: Transitional justice and excombatants, 2009: p. 158-189.

11. Goswami, R., UNSCR 1325 and Female Ex-Combatants-Case Study of the Maoist Women of Nepal. UN Women, October. http://www. unwomen. $\quad$ org/en/digitallibrary/publications/2017/5/unscr1325-and-female-ex-combatants (accessed April 19, 2019), 2015.

12. Office, I.L., Socio-Economic Reintegration of Ex-combatants: Guidelines. 2010, ILO Geneva.

13. Body, T. and S. Brown, Reintegration of ex-combatants through microenterprise: An operational framework. CPR Network: the Pearson Peacekeeping Centre, 2005.

14. Japhta, R., et al., Women-owned SMEs in Indonesia: A golden opportunity for 
local financial institutions. 2016, The World Bank.

15. Roomi, M.A., P. Harrison, and J. Beaumont-Kerridge, Women-owned small and medium enterprises in England. Journal of Small Business and Enterprise Development, 2009.

16. Suwardi, A.C., Inong Bale:

Forgotten Story in Aceh Peace Agreement. 이화여자대학교아시아여 성학센터학술대회자료집, 2016: p. 52-59.

17. Lundström, S. and S. Marhaban, Challenges and Opportunities for Female Combatants' Post-war Community Leadership: Lessons Learnt from Aceh and Mindanao.

18. Abdullah, S., Who Has Got What?, why? and How?: The Political Economy of Reintegration Policy in Aceh. Jurnal Ilmu Administrasi: Media Pengembangan Ilmu dan Praktek Administrasi, 2019. 16(2): p. 243-257.

19. Marhaban, S., Women in Post-conflict Aceh: Participation in Socio-economic and Political Processes. Weatherhead Center for International Affairs, Harvard University: Cambridge, 2018.

20. Nazaruddin, M., C. Sukmawati, and A.A. Nasution. Reintegration And Socio-Economic Transformation For Ex Combatants of The Free Aceh Movement (Gam) Post-Conflict Era In North Aceh-Indonesia. in 1st International Conference on Social and Political Development (ICOSOP 2016). 2016. Atlantis Press.

21. Yahya, R.M., et al. The Disappointed of Economic Assistance in Aceh: Study Disempowerment of the Former Free Aceh Movement's Widow. in SHS Web of Conferences. 2018. EDP Sciences.

22. Nurhasim, M., Transformasi Politik Gerakan Aceh Merdeka (GAM). Jurnal Penelitian Politik, 2016. 6(1): p. 85-98. 